\title{
Tejuino, a Traditional Fermented Beverage: Composition, Safety Quality, and Microbial Identification
}

\author{
Ángel Eduardo Rubio-Castillo ${ }^{1} \mathbb{D}$, José I. Méndez-Romero ${ }^{2} \mathbb{D}$, Ricardo Reyes-Díaz $^{2} \mathbb{D}$, Lourdes Santiago-López ${ }^{2}$, \\ Belinda Vallejo-Cordoba ${ }^{2}$, Adrián Hernández-Mendoza ${ }^{2} \mathbb{D}$, Sonia G. Sáyago-Ayerdi ${ }^{1, * \mathbb{D}}$ \\ and Aarón F. González-Córdova ${ }^{2, * \text { (D) }}$
}

1 Laboratorio Integral de Investigación en Alimentos, Tecnológico Nacional de Mexico, Instituto Tecnológico de Tepic, Av. Tecnológico No. 2595, Col. Lagos del Country, Tepic CP 63175, Nayarit, Mexico; angel.rub@icloud.com

2 Laboratorio de Calidad, Autenticidad y Trazabilidad de los Alimentos, Centro de Investigación en Alimentación y Desarrollo A.C. (CIAD), Carretera Gustavo Enrique Astiazarán Rosas, No. 46, Col. La Victoria, Hermosillo CP 83304, Sonora, Mexico; isd.mendezromero@gmail.com (J.I.M.-R.); ricardo.reyes@ciad.mx (R.R.-D.); 1santiagolopez@outlook.es (L.S.-L.); vallejo@ciad.mx (B.V.-C.); ahernandez@ciad.mx (A.H.-M.)

* Correspondence: sonia.sayago@gmail.com (S.G.S.-A.); aaronglz@ciad.mx (A.F.G.-C.)

check for updates

Citation: Rubio-Castillo, Á.E.; Méndez-Romero, J.I.; Reyes-Díaz, R.; Santiago-López, L.; Vallejo-Cordoba, B.; Hernández-Mendoza, A.; Sáyago-Ayerdi, S.G.; GonzálezCórdova, A.F. Tejuino, a Traditional Fermented Beverage: Composition, Safety Quality, and Microbial Identification. Foods 2021, 10, 2446. https://doi.org/10.3390/ foods 10102446

Academic Editors: María Jose Esteve and Jesus Blesa

Received: 12 September 2021 Accepted: 30 September 2021 Published: 14 October 2021

Publisher's Note: MDPI stays neutral with regard to jurisdictional claims in published maps and institutional affiliations.

Copyright: (c) 2021 by the authors. Licensee MDPI, Basel, Switzerland. This article is an open access article distributed under the terms and conditions of the Creative Commons Attribution (CC BY) license (https:/ / creativecommons.org/licenses/by/ $4.0 /)$.

\begin{abstract}
This study aims to analyze the chemical and microbial composition and characterize volatile compounds from the artisanal and commercial Tejuino beverage. For this, eight samples are analyzed (four artisanal and four commercial). The chemical and microbiological quality is determined by standard methods, and volatile compounds are determined by solid-phase microextraction. Overall, the physicochemical composition and microbiological quality are higher for artisanal Tejuino $(p<0.05)$. The $\mathrm{pH}$ values were 3.20 and 3.62 , and 0.76 and 0.46 meq of lactic acid for artisanal and commercial Tejuino, respectively. With volatile compounds analyzed, esters, benzenes, and aldehydes were predominant; meanwhile, ethanol was a volatile compound with the highest concentration for all samples. Saccharomyces cerevisiae and Limosilactobacillus fermentum were identified in artisanal Tejuino; yeasts of the Pichia genera and Lactiplantibacillus plantarum, for commercial Tejuino, and Enterococcus genus were identified in both samples. The characterization of both types of Tejuino allows us to update the information available on this important Mexican beverage. In addition, the isolation of lactic acid bacteria, as representative bacteria of both drinks, offers an area of opportunity to know the potential functionality of these bacteria in traditional fermented products.
\end{abstract}

Keywords: artisanal Tejuino beverage; chemical composition; volatile compounds; microbiological quality; lactic acid bacteria

\section{Introduction}

Corn is characterized by its high content of carbohydrates, protein, dietary fiber, B vitamins, and minerals, so it is considered that its consumption has beneficial effects on health [1]. This product, when is fermented by microorganisms and the presence of some endogenous enzymes (e.g., amylases, proteases, and phytases) reducing their carbohydrate content and improves the bioavailability of B vitamins [2]. Specifically, in traditional corn-based fermented beverages, a great diversity of lactic acid bacteria (LAB), molds, and yeasts have been found to utilize corn nutrients, improving the nutritional properties of the product. For example, LAB increases the free amino acids content, B complex vitamin, minerals (calcium, iron, and zinc), volatile compounds that contribute to the organoleptic characteristics of maize-based fermented beverages [3].

Tejuino is a traditional non-distilled fermented beverage from Mexican produced with germinated or nixtamalized maize. Currently, this beverage is produced and consumed mainly in the western and north-western states of Mexico (e.g., Nayarit, Jalisco, Zacatecas, 
Sinaloa, Sonora, and Chihuahua) [4]. This beverage has an important traditional ceremonial use in ethnic groups. Its production has spread within the indigenous communities. Nevertheless, Tejuino is part of the gastronomy of traditional beverages of Mexico which can be found in urban regions of Nayarit [5].

During the production of Tejuino, the temperature, types of microorganisms, $\mathrm{pH}$, production zone, and fermentation time are variables that determine the nutritional and microbiological composition [6]. The fermentation process for Tejuino is spontaneous and uncontrolled, principally for the artisanal kind; therefore, the sensory characteristics and quality are important variables due to several microorganism types being involved, such as the Saccharomyces genus and LAB, principally [7]. These microorganisms contribute to the flavor development through a carbohydrate metabolism, proteolysis, and amino acid catabolism, as well lipolysis and a fatty acids metabolism $[4,5,8]$. In this sense, some microorganisms have been identified in traditional beverages produced from corn, such as Saccharomyces cerevisiae, Candida inconspicua, amylolytic LAB (Zymomona mobilis), and LAB (Lactobacillus plantarum, Lactococcus lactis, Lactobacillus acidophilus, and Lactobacillus casei), which are involved in the flavor development [9].

Regarding the flavor, it is one of the most important sensory attributes of traditional fermented beverages. The taste of these beverages is determined by the presence of volatile compounds obtained by the metabolism of carbohydrates, proteins, lipids, free amino acids, and microbiota action $[10,11]$. However, the information available on these properties for Tejuino beverage has not been reported for the last 20 years. This study aims to analyze the chemical and microbial composition and characterization of volatile compounds from artisanal and commercial Tejuino beverages.

\section{Materials and Methods}

\subsection{Collection of Samples}

Samples of commercial Tejuino were purchased at local mobile stores and artisanal Tejuino from Wixárika ethnic groups from Nayarit, Mexico. Samples were collected in two seasons (winter and spring) in different regions of Nayarit. Samples from artisanal Tejuino were codified as "AR" (El Nayar), "AY" (La Yesca), "AW" (Wirikuta), and "TZ" (Zitacua); commercial Tejuino samples were codified as "TC" (City center), "TL" (Leon Street), "TM" (Plaza de la Música), and "TT" (Tecnológico Zone), obtaining a total of eight different beverages. All samples were transported under refrigeration conditions to the laboratory for further analysis.

A fresh sample $(1 \mathrm{~L})$ was used for physicochemical analysis ( $\mathrm{pH}$, acidity, moisture, total solids) of volatile compounds; for the microbiological analysis, $200 \mathrm{~mL}$ of sample was aseptically obtained and placed in sterile flasks and immediately analyzed. On the other hand, $800 \mathrm{~mL}$ was frozen at $-80^{\circ} \mathrm{C}$ and lyophilized (FreeZone 6, Labconco, Kansas City, USA) to determine fat, protein, and ash.

\subsection{Physicochemical Analysis}

Physicochemical parameters of Tejuino were determinate according to standard methodologies [12]; total solids, moisture by difference, were determined by the oven drying method (method 925.23), protein (micro-Kjeldahl method 991.20), fat (Soxhlet method: 989.04), ash (gravimetric method: 990.19), and acidity (method: 920.12). Concentration of carbohydrates was determinate by difference: $(100-$ (total solids + protein + fat + ashes)) [13]. Furthermore, $\mathrm{pH}$ was recorded using a Microprocessor $\mathrm{pH}$ meter (Hanna Instruments, pH 211, Woonsocket, RI, USA).

\subsection{Microbiological Analysis}

The microbiology quality was determined following the methodology reported by Torres-Llanez et al. [14]. For this, $10 \mathrm{~mL}$ of each Tejuino sample was mixed with $90 \mathrm{~mL}$ of peptone water at room temperature and series of 10 -fold dilutions were performed. Total Coliform Bacteria (TCB) was evaluated by the most probable number (MPN) method 
in Lauryl Sulfate Broth (BD Difco, Sparks, MD, USA), and incubated at $25^{\circ} \mathrm{C}$ for $48 \mathrm{~h}$. Aerobic mesophilic bacteria (AMB) in Plate Count Agar (BD Difco) at $35^{\circ} \mathrm{C}$ for $48 \mathrm{~h}$; molds and yeasts (MY) in Potato Dextrose Agar (BD Difco) acidified at $\mathrm{pH} 3.5$ with tartaric acid solution $(10 \% w / v)$ (FAGALAB, Sinaloa, Mexico) at $25{ }^{\circ} \mathrm{C}$ for 5 days. The cell count was reported as $\log _{10}$ colony-forming units $(\mathrm{CFU}) / \mathrm{mL}$. All analyses were performed following the specifications of the Official Mexican Standard (NOM) [15-17].

On the other hand, LAB concentration of Streptococcus spp and Lactococcus spp was determined in M17 agar (BD Difco) supplemented with lactose and dextrose (5\%) and incubated at $42{ }^{\circ} \mathrm{C}$ and $30{ }^{\circ} \mathrm{C}$ for $48 \mathrm{~h}$, respectively; Lactobacillus spp. in de Man, Rogosa and Sharpe agar (MRS BD Difco) at $37^{\circ} \mathrm{C}$ for $48 \mathrm{~h}$ under anaerobic conditions (BD GasPak Anaerobe Container System, MD, USA). The cell concentration was reported as $\log _{10} \mathrm{CFU} / \mathrm{mL}$.

\subsection{Isolation of Lactic Acid Bacteria and Yeast}

A minimum of two representative LAB colonies was obtained for each medium selected (M17 and MRS agar). Three culture steps in agar-broth-agar were performed, and colony morphology characteristics such as shape, margin, and elevation were considered [18]. Later, the bacteria and yeasts were grown in a specific medium for $18 \mathrm{~h}$. A catalase and oxidase test by Kovacs method and Gram staining were performed. The isolated strains were visualized by microscopy $(100 \times$ objective, Modelo AXIO, ZEISS Corporation, Germany). Finally, the strains were stored at $-80{ }^{\circ} \mathrm{C}$ using $80 \%$ glycerol $(v / v)[19]$.

\subsection{Identification of $L A B$ and Yeasts Strains}

LAB identification; each strain was cultured for $18 \mathrm{~h}$ in MRS (anaerobic conditions), M17 broth at $37^{\circ} \mathrm{C}, 30^{\circ} \mathrm{C}$, and $40^{\circ} \mathrm{C}$. Then, $1 \mathrm{~mL}$ of each strain was centrifuged $(16,000 \times g, 10 \mathrm{~min})$ (Spectrafuge 16M, Labnet, Woodbridge, NJ, USA) to obtain a pellet and the DNA extraction was performed using the commercial protocol kit PrepMan Ultra Sample Preparation Reagent (Applied Biosystems, Foster City, CA, USA). The DNA purity was determinate at $260 \mathrm{~nm}$ (NanoDrop 2000c UV-Vis, Thermo Fisher Scientific, Wilmington, DE, USA), and the DNA integrity was evaluated in agarose gel (Sigma-Aldrich, MO, USA) electrophoresis $(80 \mathrm{~V}, 30 \mathrm{~min})$. It was visualized in a photodocumenter (Gel DocTM XR+System, Bio-Rad, CA, USA). The analysis of the $16 \mathrm{~S}$ rRNA method was performed following the protocol of MicroSEQ ${ }^{\mathrm{TM}} 500$ identification Systems (Applied Biosystems). The PCR conditions for amplification was performed in a thermocycler endpoint (Eppendorf, Hamburg, Germany). The PCR conditions for denaturation were at at $95^{\circ} \mathrm{C}$ for $10 \mathrm{~min}, 30$ cycles of $95^{\circ} \mathrm{C}$ for $30 \mathrm{~s}$, $60{ }^{\circ} \mathrm{C}$ for $30 \mathrm{~s}$, and $72{ }^{\circ} \mathrm{C}$ for $45 \mathrm{~s}$, final extension of $72{ }^{\circ} \mathrm{C}$ for $10 \mathrm{~min}$ and final step at $4{ }^{\circ} \mathrm{C}$. For the sequencing, 25 cycles were performed at $96^{\circ} \mathrm{C}$ for $10 \mathrm{~s}, 50^{\circ} \mathrm{C}$ for $5 \mathrm{~s}$, and $60^{\circ} \mathrm{C}$ for 4 min.

For the identification of yeast, this was grown in PDA broth at $25^{\circ} \mathrm{C}, 18 \mathrm{~h}$. Subsequently, $1 \mathrm{~mL}$ of culture was centrifuged $(16,000 \times \mathrm{g}, 10 \mathrm{~min}$ ) (Spectrafuge $16 \mathrm{M})$ for the extraction of DNA using the commercial protocol Wizard Genomic DNA Purification Kit (Promega, Madison, WI, USA). The amplification method was based on the MicroSEQ ${ }^{\mathrm{TM}}$ D2 rDNA Fungal Sequencing Kit (Applied Biosystems). The PCR conditions for amplification initial step was at $95^{\circ} \mathrm{C}$ for $10 \mathrm{~min}, 35$ cycles at $95^{\circ} \mathrm{C}$ for $30 \mathrm{~s}, 53^{\circ} \mathrm{C}$ for $30 \mathrm{~s}, 72{ }^{\circ} \mathrm{C}$ for $1 \mathrm{~min}$, final extension $72^{\circ} \mathrm{C}$ for $10 \mathrm{~min}$. For the sequencing run, 25 cycles were performed at $96{ }^{\circ} \mathrm{C}$ for $10 \mathrm{~s}, 50^{\circ} \mathrm{C}$ for $5 \mathrm{~s}$, and $60^{\circ} \mathrm{C}$ for $4 \mathrm{~min}$.

Each PCR product was purified with ExoSAP-IT ${ }^{\mathrm{TM}}$ PCR Product Cleanup Reagent (Affymetrix, Santa Clara, CA, USA) and, then, sequencing reactions were purified using the BigDye Xterminator ${ }^{\mathrm{TM}}$ purification kit (Applied Biosystems) and, the purified sequencing reactions were examined in a 3500 Genetic Analyzer (Applied Biosystems). The sequences obtained were analyzed in the MicroSEQ software v2.0 (Applied Biosystems) and compared with the library of GenBank database (Accessed 1 January 2021; http:/ / www.ncbi.nlm.nih. 
gov / BLAST /) using the Blast program of NCBI to determinate the identity of the strains. Sequences with a percentage identity $>99 \%$ were considered to belong to the same species.

2.6. Analysis of Volatile Compounds by Solid-Phase Microextraction Gas Chromatography Mass Spectrometry (SPME-GC-MS)

Headspace solid-phase microextraction and gas chromatography (HS-SPME-GC) method were used following the methodology reported by Reyes-Díaz et al. [20]. For this, fresh Tejuino samples $(5 \mathrm{~mL}), 2 \mathrm{~g}$ of $\mathrm{NaCl}$, and $5 \mu \mathrm{L}$ of dodecanoic acid methyl ester (internal standard, 1000 ppm in methanol, PolyScience C., Niles, IL, USA) were placed in screw-capped glass vials $(20 \mathrm{~mL}, 22.75 \times 75 \mathrm{~mm})$ and sealed with headspace vial caps (18 mm magnetic PTFE/Sil, Agilent Technologies, Basel, Switzerland). Then, vials were placed on the GC Sampler system (GC autosampler 80, Agilent Technologies). Before SPME extraction, samples were allowed to equilibrate at $70{ }^{\circ} \mathrm{C}(150 \mathrm{rpm}, 30 \mathrm{~min})$. Afterward, a $75 \mu \mathrm{m}$ CAR-PDMS fiber (Supelco Co., Bellefonte, PA, USA) was exposed to the sample headspace while shaking $(150 \mathrm{rpm})$ at $70^{\circ} \mathrm{C}$ for $60 \mathrm{~min}$. Then, the fiber was withdrawn into the needle of the SPME device and immediately desorbed at $250{ }^{\circ} \mathrm{C}$ for $10 \mathrm{~min}$ in splitless mode. Volatile compounds were determined into GC-MS System (Agilent Technologies 7890A/5975C, Santa Clara, CA, USA), and the injector was provided with an inlet liner (78.5 mm $\times 6.5 \mathrm{~mm}$ O.D. $\times 0.75 \mathrm{~mm}$ I.D., Sigma-Aldrich, St. Louis, MO, USA). Helium was used as the carrier gas at $1.5 \mathrm{~mL} / \mathrm{min}$.

The compounds were separated by a high-polarity DB-WAX column (60 m length, $0.25 \mathrm{~mm}$ I.D., $0.25-\mu \mathrm{m}$ film thickness, Agilent J\&W Scientific) with a carrier gas at $1 \mathrm{~mL} / \mathrm{min}$. The initial oven temperature was held at $45^{\circ} \mathrm{C}$ for $12.5 \mathrm{~min}$, increased to $114{ }^{\circ} \mathrm{C}$ (rate of $4{ }^{\circ} \mathrm{C} / \mathrm{min}$ for $6 \mathrm{~min}$ ), then to $143^{\circ} \mathrm{C}$ (rate of $7^{\circ} \mathrm{C} / \mathrm{min}$ for $15 \mathrm{~min}$ ), and, finally, increased to $165{ }^{\circ} \mathrm{C}$ (rate of $15^{\circ} \mathrm{C} / \mathrm{min}$, for $15 \mathrm{~min}$ ). Volatile compounds were tentatively identified by comparing their spectra to those from the National Institute of Standards and Technology MS library (Soft. v. 2.0 g., 2011).

\subsection{Statistical Analysis}

All dates were analyzed using one way-ANOVA, ant the differences among samples were compared using the Fisher LSD test with $p<0.05$. Principal component analysis (PCA) by factor loadings and factor scores was performed to obtain volatile compounds data; clusters were determined by k-means clustering analysis. All the statistical analyses were performed by using the NCSS-2007 statistical software (Kaysville, UT, USA).

\section{Results and Discussion}

\subsection{Chemical Composition}

The results of the physicochemical composition of the samples of Tejuino are shown in Table 1. Overall, the parameters evaluated showed differences $(p<0.05)$ among the samples evaluated. In particular, the artisanal samples presented a higher moisture (89.73-92.66\%) compared to the commercial samples (83.35-88.29\%) and, therefore, the TS were lower for the artisan samples (7.34 to $10.28 \%)$. The protein content showed a difference $(p<0.05)$, being 7.3-fold higher for the artisanal samples than commercial. On the other hand, the fat content was 1.81-fold and ash was 3.10-fold higher for artisanal samples $(p<0.05)$. On the contrary, the CHOS content was higher for commercial samples with a mean of $78.70 \%$; meanwhile, for artisanal samples, it was $62.48 \%(p<0.05)$. The $\mathrm{pH}$ range was 2.91 to 3.52 and 3.36 to 3.96; for acidity there was 0.4 to 1.22 and 0.27 to 0.57 meq of lactic acid/L for the artisanal and commercial beverages, respectively, the artisanal beverages being the ones to show the higher acidity. Although, a difference of $(p>0.05)$ among artisanal and commercial Tejuino was seen. 
Table 1. Physicochemical composition of artisanal and commercial Tejuino beverages from Nayarit, Mexico.

\begin{tabular}{|c|c|c|c|c|c|c|c|c|}
\hline \multirow{2}{*}{ Item } & \multicolumn{4}{|c|}{ Artisanal Tejuino } & \multicolumn{4}{|c|}{ Commercial Tejuino } \\
\hline & AR & AW & AY & $\mathbf{A Z}$ & TC & TL & TM & TT \\
\hline${ }^{1}$ Moisture & $89.8 \pm 0.22 \mathrm{bc}$ & $92.66 \pm 0.34^{\mathrm{d}}$ & $89.73 \pm 0.07^{b c}$ & $91.66 \pm 1.20^{\mathrm{cd}}$ & $87.70 \pm 1.01^{b}$ & $84.65 \pm 0.32^{a}$ & $88.29 \pm 0.02^{b}$ & $83.35 \pm 3.77^{a}$ \\
\hline${ }^{1} \mathrm{TS}$ & $10.2 \pm 0.22^{b c}$ & $7.34 \pm 0.34^{\mathrm{a}}$ & $10.28 \pm 0.07^{b c}$ & $8.34 \pm 1.20^{\mathrm{ab}}$ & $12.30 \pm 1.01^{c}$ & $15.36 \pm 0.33^{\mathrm{d}}$ & $11.72 \pm 0.02^{c}$ & $16.65 \pm 3.77^{\mathrm{d}}$ \\
\hline${ }^{1}$ Protein & $18.60 \pm 0.92^{f}$ & $27.05 \pm 0.32^{g}$ & $16.50 \pm 0.12^{\mathrm{e}}$ & $6.17 \pm 0.08^{d}$ & $2.84 \pm 0.14^{b c}$ & $2.32 \pm 0.25^{b}$ & $3.00 \pm 0.25^{c}$ & $1.23 \pm 0.01^{\mathrm{a}}$ \\
\hline${ }^{1}$ Fat & $7.67 \pm 0.00^{d}$ & $9.01 \pm 0.58^{\mathrm{d}}$ & $5.67 \pm 0.00^{c}$ & $4.85 \pm 0.38^{c}$ & $4.72 \pm 0.04^{b}$ & $4.23 \pm 0.00^{b}$ & $4.02 \pm 0.48^{b}$ & $2.04 \pm 0.00^{\mathrm{a}}$ \\
\hline${ }^{1}$ CHOS * & $59.42 \pm 1.25^{d}$ & $49.35 \pm 0.10^{\mathrm{e}}$ & $63.62 \pm 0.14^{c}$ & $77.53 \pm 1.23^{a b}$ & $79.27 \pm 1.24^{\mathrm{ab}}$ & $76.70 \pm 0.97^{\mathrm{b}}$ & $79.32 \pm 0.69^{a b}$ & $79.52 \pm 3.77^{a}$ \\
\hline${ }^{1}$ Ash & $3.78 \pm 0.57^{\mathrm{d}}$ & $7.24 \pm 0.02^{\mathrm{e}}$ & $4.01 \pm 0.13^{\mathrm{d}}$ & $2.73 \pm 0.08^{c}$ & $0.87 \pm 0.06^{\mathrm{a}}$ & $2.39 \pm 0.04^{c}$ & $1.93 \pm 0.01^{b}$ & $0.56 \pm 0.01^{\mathrm{a}}$ \\
\hline $\mathrm{pH}$ & $2.91 \pm 0.01^{\mathrm{a}}$ & $3.52 \pm 0.01^{c}$ & $2.91 \pm 0.01^{\mathrm{a}}$ & $3.48 \pm 0.01^{b}$ & $3.63 \pm 0.01^{d}$ & $3.96 \pm 0.01 \mathrm{e}$ & $3.52 \pm 0.01^{c}$ & $3.36 \pm 0.01^{b}$ \\
\hline Acidity $\ddagger$ & $0.4 \pm 0.01^{\mathrm{b}}$ & $0.76 \pm 0.01^{\mathrm{f}}$ & $0.68 \pm 0.01 \mathrm{e}^{\mathrm{e}}$ & $1.22 \pm 0.01 \mathrm{~g}$ & $0.27 \pm 0.02^{\mathrm{a}}$ & $0.57 \pm 0.03^{d}$ & $0.55 \pm 0.02^{\mathrm{d}}$ & $0.47 \pm 0.01^{\mathrm{c}}$ \\
\hline
\end{tabular}

Values show the means \pm standard deviation $(n=3) ;{ }^{1}$ Values are expressed as percentage. Different letters for the same row indicate significant differences $(p \leq 0.05)$ among samples. AR: El Nayar; AW: Wirikuta; AY: La Yesca; and AZ: Zitacua; TC: Tepic Center; TL: León Street; TM: Music square; TT: Tecnólogico zone; TS: total solids; CHOS *: carbohydrates, ${ }^{\ddagger}$ meq LA/mL.

The elaboration process could explain the difference in the physicochemical composition between artisanal and commercial Tejuino beverages. Corn germination is conducted in dark conditions; then, the sun drying process proceeds (2-3 days), finally being mixed with water. The liquid was cooking and the sediments were fermented for $24 \mathrm{~h}$ at room temperature. Afterwards, both samples were mixed, filtered, and the filtered sample was left to ferment for 7 days. On the other hand, commercial Tejuino is produced from nixtamalized corn, followed by the addition of piloncillo to initiate fermentation for 12 $24 \mathrm{~h} \mathrm{[5].} \mathrm{In} \mathrm{particular,} \mathrm{the} \mathrm{combined} \mathrm{processes} \mathrm{of} \mathrm{fermentation} \mathrm{and} \mathrm{germination} \mathrm{improve}$ the nutritional compositions of beverages. A study reported by Hiran et al. [21] showed an enhanced - up to two-fold - protein content of fermented germinated maize seeds by LAB. Furthermore, during germination, endogenous enzymes hydrolyze the maize compounds, e.g., prolamins and glutelins [22].

The CHOS concentration for commercial Tejuino may be influenced by the addition of "piloncillo" (brown sugar, prepared from the undistilled juice of sugar that contains $>70 \%$ of sugar). On the contrary, the starch present in the germinated corn is hydrolyzed into sugars such as glucose and saccharose [23]. During the fermentation, the microorganisms reduce the carbohydrates content up to $20 \%$ [21], as well as the ash content, but enhance the protein content [24].

The values of $\mathrm{pH}$ and acidity for artisanal and commercial Tejuino did not show differences, but AR and AY were the lowest. Fermentation is spontaneous and uncontrolled in traditional fermented products; artisanal Tejuino has up to 6 days of fermentation, where several microorganisms and enzymatic processes hydrolyze molecules such as lipids, proteins, and carbohydrates. For instance, Ben Omar and Ampe, [25] associated the $\mathrm{pH}$ reduction due to organic products (e.g., lactic acid, formic acid) and ethanol by the action of microorganisms. Although the fermentation time for commercial Tejuino is only 12 to $24 \mathrm{~h}$, the "Tejuino viejo" (starter culture unless $24 \mathrm{~h}$ of fermentation), and, finally, some additives are incorporate, such as salt and lemon juice, which may influence the $\mathrm{pH}$ values.

\subsection{Microbial Quality}

The microbial quality of Tejuino beverages is shown in Table 2. Overall, the artisanal samples showed the highest concentrations for all types of microorganisms evaluated. Only total coliform bacteria were absent in all samples. All cell concentrations were different $(p<0.05)$ among samples, but higher for artisanal beverages. The MY range was 7.32 to 8.47 and 4.74 to $7.93 \log 10 \mathrm{CFU} / \mathrm{mL}$; $\mathrm{AMB}$ was 7.27 to 8.66 and 7.17 to $7.5993 \log _{10} \mathrm{CFU} / \mathrm{mL}$ for artisanal and commercial beverages, respectively. 
Table 2. Microbiological quality of artisanal and commercial Tejuino beverages from Nayarit, Mexico.

\begin{tabular}{|c|c|c|c|c|c|c|c|c|}
\hline \multirow{2}{*}{ Microorganisms } & \multicolumn{4}{|c|}{ Artisanal Tejuino } & \multicolumn{4}{|c|}{ Commercial Tejuino } \\
\hline & AR & AW & AY & $\mathbf{A Z}$ & TC & TL & TM & TT \\
\hline MY & $8.33 \pm 0.01^{g}$ & $8.23 \pm 0.05^{f}$ & $8.47 \pm 0.01^{\mathrm{h}}$ & $7.32 \pm 0.02^{d}$ & $7.26 \pm 0.04^{c}$ & $6.76 \pm 0.02^{b}$ & $7.93 \pm 0.03^{\mathrm{e}}$ & $4.74 \pm 0.04^{\mathrm{a}}$ \\
\hline $44 \mathrm{AMB}$ & $8.66 \pm 0.01 \mathrm{e}$ & $8.23 \pm 0.01^{c}$ & $8.40 \pm 0.01^{\mathrm{d}}$ & $7.27 \pm 0.02^{a}$ & $7.15 \pm 0.01^{\mathrm{a}}$ & $7.11 \pm 0.38^{a}$ & $7.59 \pm 0.05^{b}$ & $7.17 \pm 0.06^{a}$ \\
\hline $\mathrm{TCB}^{*}$ & $<3$ & $<3$ & $<3$ & $<3$ & $<3$ & $<3$ & $<3$ & $<3$ \\
\hline \multicolumn{9}{|c|}{ Lactic Acid Bacteria } \\
\hline Lactobacillus spp. & $8.28 \pm 0.02^{c}$ & $8.13 \pm 0.03^{c}$ & $8.33 \pm 0.01^{c}$ & $6.98 \pm 0.01^{\mathrm{a}}$ & $7.18 \pm 0.03^{a}$ & $7.14 \pm 0.33^{a}$ & $7.64 \pm 0.01^{b}$ & $7.13 \pm 0.01^{\mathrm{a}}$ \\
\hline Lactococcus spp. & $8.46 \pm 0.10^{b}$ & $8.22 \pm 0.01^{b}$ & $8.47 \pm 0.01^{b}$ & $7.19 \pm 0.05^{a}$ & $7.28 \pm 0.03^{a}$ & $6.86 \pm 0.68^{a}$ & $7.42 \pm 0.02^{\mathrm{a}}$ & $7.15 \pm 0.07^{a}$ \\
\hline Streptococcus spp. & $8.11 \pm 0.01^{\mathrm{d}}$ & $8.18 \pm 0.05^{d}$ & $8.46 \pm 0.10^{\mathrm{e}}$ & $7.18 \pm 0.01 \mathrm{bc}$ & $7.26 \pm 0.01 \mathrm{bc}$ & $6.87 \pm 0.80^{\mathrm{ab}}$ & $6.89 \pm 0.11^{b}$ & $7.15 \pm 0.07^{b c}$ \\
\hline
\end{tabular}

Values represent the means \pm standard deviation $(n=3)$. Different letters for the same microorganisms group indicate significant differences $(p \leq 0.05)$ among samples. AR: El Nayar; AW: Wirikuta; AY: La Yesca; AZ: Zitacua; TC: Tepic Center; TL: León Street; TM: Music square; TT: Tecnólogico zone. Total count of molds and yeasts (MY), aerobic mesophilic bacteria (AMB), and total coliform bacteria (TCB). ${ }^{*}$ MPN / mL.

The physicochemical composition of Tejuino determines the microbial diversity. Some conditions of low $\mathrm{pH}$ may be a factor that affects the presence of some microorganisms. For instance, LAB predominates in an acidic environment, but there was less or an absence of total enterobacteria [26]. On the contrary, LAB were the predominant group in these beverages. During the nixtamalization processes, the concentration of carbohydrates was reduced, starch being the main carbohydrate available for LAB [27]. This could explain why the commercial beverage had a lower concentration of LAB. Regarding artisanal Tejuino, it showed the highest concentration. This great diversity in the concentration of microorganisms has been reported in other traditional maize-based beverages, such as Pozol [25,27], Atole Agrio [28], and commercial Tejuino [29].

The microbiological quality for both beverages showed marked differences in concentration, which could be attributed to the fact that both processes are non-standardized methods, indicating an absence of good manufacturing practices. However, the presence of microorganisms determines the sensory characteristics of this type of beverage, and even the possible health effects attributed to the great diversity of metabolites present, and even the microbiota present have been documented in other beverages [30]. Moreover, during spontaneous fermentation, bacteria and yeasts produce several metabolites available for other microorganisms, showing a microbial diversity [31].

\subsection{Identification of $L A B$ and Yeast Strains}

$\mathrm{LAB}$ and yeast were identified molecularly by comparing the $16 \mathrm{~S}$ rRNA gene sequences with NCBI sequences available in this database (Table 3). Twenty-eight strains were identified with a $100 \%$ similarity except for strain number twenty-eight, which showed $95 \%$. The main yeasts identified were Pichia occidentalis and Pichia kudriavzevii for commercial Tejuino, and Saccharomyces cerevisiae for the artisanal Tejuino samples. On the other hand, LAB identification, the predominant bacteria identified were Limosilactobacillus fermentum (five strains) and Lactiplantibacillus plantarum (three strains) for commercial and artisanal Tejuino, Enterococcus durans (five strains) for commercial Tejuino and two strains for artisanal Tejuino, Enterococcus faecium and Staphylococcus warneri (two strains) for commercial, and Lactococcus lactis for artisanal Tejuino.

In this sense, important characteristics were documented for some identified microorganisms, which could be of great interest for future studies. In the yeast group, Pichia genus has been isolated from Chicha (indigenous Andean beer) [32], and has been reported as a start culture [33]. Pichia kudriavzevii has been characterized by the production of biofilms at a low $\mathrm{pH}$ [34]; Pichia occidentalis, with the potential to produce phytases and bioethanol in prolonged fermentation times [35,36], also showed a stress tolerance [32]. This yeast has been reported in other fermented beverages such as cachaça, tequila, mezcal, wine, and beer [37]. Saccharomyces cerevisiae has been widely reported for its fermentation properties and ethanol production [32,38], and is present in several traditional fermented beverages of Mexico such as Atole agrio [39], Tesgüino [6], and Tepache [40]. 
Table 3. Phylogenetic identification results of isolated yeasts and bacteria strains of commercial and artisanal Tejuino.

\begin{tabular}{|c|c|c|c|c|c|}
\hline \multicolumn{3}{|c|}{ Commercial Tejuino } & \multicolumn{3}{|c|}{ Artisanal Tejuino } \\
\hline Strain & Identification & Accession & Strain & Identification & Accession \\
\hline 1 & Pichia occidentalis & MN904761.1 & 4 & Saccharomyces cerevisiae & \multirow{3}{*}{ MT649488.1 } \\
\hline 2 & Pichia kudriavzevii & \multirow{2}{*}{ JF715184.1 } & 5 & Saccharomyces cesevisiae & \\
\hline 3 & Pichia kudriavzevii & & 6 & Saccharomyces cerevisiae & \\
\hline 7 & Acetobacter orientalis & MT416429.1 & 11 & Lactococcus lactis & MT645510.1 \\
\hline 9 & Enterococcus faecium & MK332450.1 & 17 & Lactiplantibacillus plantarum & \multirow{3}{*}{ СР050805.1 } \\
\hline 12 & Limosilactobacillus fermentum & \multirow{5}{*}{ MT613608.1 } & 18 & Lactiplantibacillus plantarum & \\
\hline 13 & Limosilactobacillus fermentum & & 20 & Lactiplantibacillus plantarum & \\
\hline 14 & Limosilactobacillus fermentum & & 10 & Enterococcus durans & \multirow{2}{*}{ MT604840.1 } \\
\hline 15 & Limosilactobacillus fermentum & & 27 & Enterococcus durans & \\
\hline 16 & Limosilactobacillus fermentum & & 28 & Enterococcus hirae & KX752853.1 \\
\hline 21 & Staphylococcus warneri & \multirow{2}{*}{ MT642942.1 } & & & \\
\hline 22 & Staphylococcus warneri & & & & \\
\hline 8 & Enterococcus durans & \multirow{5}{*}{ MT604840.1 } & & & \\
\hline 23 & Enterococcus durans & & & & \\
\hline 24 & Enterococcus durans & & & & \\
\hline 25 & Enterococcus durans & & & & \\
\hline 26 & Enterococcus durans & & & & \\
\hline
\end{tabular}

$\mathrm{LAB}$ are the dominant microorganism in several foods, but the existence of consortium helps to promote the diversity of microorganisms; LAB produces organic acids that decrease $\mathrm{pH}$ and promote the growth of yeast [41]. Furthermore, LAB contributes to food preservation and flavor development by organic acid production. Some reports show increasing digestibility in vitro of the proteins and starch of maize due to LAB consortium by fermentation [42]. However, we found undesirable bacteria such as Staphylococcus, related to food handling practices [43].

During spontaneous fermentation, bacteria and yeasts release several metabolites and promote the growth of other microorganisms. Thus, this interaction enhances the nutritional, rheological, and sensory properties of food [31]. This effect has been documented for other traditional beverages $[6,39,40]$.

\subsection{Volatile Compounds}

The volatile compounds found in the eight samples of artisanal and commercial Tejuino beverages are shown in Table 4. Eighty-nine volatile compounds were identified; however, only ten compounds were detected in all beverages (decanoic acid ethyl ester, acetic acid 2-phenylethyl ester, hexadecanoic acid ethyl ester, ethanol, 1-pentanol, phenylethyl alcohol, octanoic acid, benzaldehyde, creosol, and phenol, 4-ethyl) and showed a difference among artisanal and commercial beverages $(p<0.05)$ except for cresol and phenol 4ethyl. In this regard, esters, benzenes, and aldehydes were the highest number of volatile compounds identified (26,17 and 12 compound, respectively). Our data showed the highest relative abundance of volatile compounds for artisanal samples, the esters group being the predominant compounds. The "AR" beverage showed the highest esters; meanwhile, "AW" was for aldehydes and benzenes. Esters may provide fruity and floral flavors in some food; thus, decreasing the astringent aroma of fatty acids and amines [44]. 
Table 4. Volatile compounds identified in Tejuino beverage by headspace solid-phase microextraction and GC-MS (ppm).

\begin{tabular}{|c|c|c|c|c|c|c|c|c|c|}
\hline \multirow{2}{*}{ No. } & \multirow{2}{*}{ Volatile Compound } & \multirow{2}{*}{ RT } & \multicolumn{4}{|c|}{ Artisanal Tejuino } & \multicolumn{3}{|c|}{ Commercial Tejuino } \\
\hline & & & AR & AW & AY & TC & TL & TM & TT \\
\hline \multicolumn{10}{|c|}{ Esters } \\
\hline 1 & Ethyl acetate & 6.01 & $0.104 \pm 0.06^{\mathrm{a}}$ & $0.081 \pm 0.05^{\mathrm{a}}$ & $1.041 \pm 1.29^{\mathrm{a}}$ & ND & $0.008 \pm 0.01^{\mathrm{a}}$ & $0.049 \pm 0.02^{\mathrm{a}}$ & $0.008 \pm 0.01^{\mathrm{a}}$ \\
\hline 2 & Butanoic acid, ethyl ester & 10.2 & ND & ND & ND & ND & ND & ND & $0.010 \pm 0.00^{\mathrm{a}}$ \\
\hline 3 & Pentanoic acid, 3-methyl-, ethyl ester & 21.36 & $0.008 \pm 0.01^{\mathrm{a}}$ & ND & $0.021 \pm 0.00^{\mathrm{a}}$ & ND & ND & ND & ND \\
\hline 4 & Propanoic acid, 2-hydroxy-, ethyl ester, (S) & 26.4 & ND & ND & $0.005 \pm 0.00^{\mathrm{a}}$ & ND & ND & ND & ND \\
\hline 5 & Octanoic acid, ethyl ester & 30.76 & $0.42 \pm 0.18^{\mathrm{a}}$ & $0.139 \pm 0.07^{\mathrm{a}}$ & ND & $0.907 \pm 0.77^{\mathrm{a}}$ & $0.381 \pm 0.41^{\mathrm{a}}$ & $0.019 \pm 0.02^{a}$ & $0.005 \pm 0.00^{\mathrm{a}}$ \\
\hline 6 & Nonanoic acid, ethyl ester & 34.86 & $0.026 \pm 0.01^{\mathrm{a}}$ & $0.0372 \pm 0.05^{\mathrm{a}}$ & ND & $0.015 \pm 0.01^{\mathrm{a}}$ & ND & ND & $\mathrm{DN}$ \\
\hline 7 & Decanoic acid, methyl ester & 37.47 & ND & ND & ND & ND & ND & ND & $\mathrm{DN}$ \\
\hline 8 & Decanoic acid, ethyl ester * & 39.19 & $0.998 \pm 0.4^{\mathrm{d}}$ & $0.046 \pm 0.02^{\mathrm{abc}}$ & $0.875 \pm 0.06^{\mathrm{cd}}$ & $0.252 \pm 0.14^{\mathrm{a}}$ & $0.753 \pm 0.61^{\mathrm{bcd}}$ & $0.035 \pm 0.02 \mathrm{ab}$ & $0.008 \pm 0.00^{\mathrm{bcd}}$ \\
\hline 9 & Octanoic acid, 3-methylbutyl ester & 39.82 & $0.029 \pm 0.01$ & ND & ND & ND & ND & ND & ND \\
\hline 10 & Butanedioic acid, diethyl ester & 40.58 & $0.005 \pm 0.00^{\mathrm{a}}$ & ND & ND & ND & $0.015 \pm 0.00^{\mathrm{a}}$ & ND & ND \\
\hline 11 & Ethyl 9-decenoate & 40.68 & $0.027 \pm 0.01^{\mathrm{a}}$ & ND & ND & $0.044 \pm 0.02^{\mathrm{a}}$ & ND & $0.004 \pm 0.00^{\mathrm{a}}$ & ND \\
\hline 12 & Undecanoic acid, methyl ester & 40.82 & ND & ND & ND & ND & ND & ND & ND \\
\hline 13 & Benzeneacetic acid, ethyl ester & 44.12 & $0.008 \pm 0.00^{\mathrm{a}}$ & $0.024 \pm 0.01^{\mathrm{a}}$ & $0.023 \pm 0.00^{\mathrm{a}}$ & ND & ND & ND & ND \\
\hline 14 & Acetic acid, 2-phenylethyl ester* & 45.45 & $0.107 \pm 0.11^{\mathrm{a}}$ & $0.175 \pm 0.07^{\mathrm{a}}$ & $0.491 \pm 0.05^{\mathrm{a}}$ & $0.148 \pm 0.18^{a}$ & $0.349 \pm 0.02^{\mathrm{a}}$ & $0.998 \pm 0.52^{b}$ & $0.043 \pm 0.03^{\mathrm{ab}}$ \\
\hline 15 & Dodecanoic acid, ethyl ester & 46.84 & $0.430 \pm 0.15^{\mathrm{ab}}$ & $0.052 \pm 0.02 \mathrm{ab}$ & $0.516 \pm 0.03 \mathrm{ab}$ & $0.017 \pm 0.01^{\mathrm{a}}$ & $0.056 \pm 0.01^{b}$ & $0.01 \pm 0.01^{b}$ & $0.007 \pm 0.00^{b}$ \\
\hline 18 & $2(3 \mathrm{H})$-Furanone, dihydro-5-pentyl & 58.3 & $0.077 \pm 0.04^{\mathrm{a}}$ & $0.382 \pm 0.14^{\mathrm{a}}$ & ND & $0.31 \pm 0.17^{\mathrm{a}}$ & ND & ND & ND \\
\hline 19 & Nonanoic acid, 9-oxo-, ethyl ester & 61.81 & $0.003 \pm 0.00^{\mathrm{a}}$ & ND & $0.002 \pm 0.00^{\mathrm{a}}$ & ND & ND & ND & ND \\
\hline 20 & Diethyl suberate & 62.47 & $0.019 \pm 0.01$ & ND & ND & ND & ND & ND & ND \\
\hline 21 & Pentadecanoic acid, ethyl ester & 63.97 & $0.004 \pm 0.00^{\mathrm{a}}$ & ND & $0.025 \pm 0.00^{\mathrm{a}}$ & ND & ND & ND & ND \\
\hline 22 & Hexadecanoic acid, methyl ester & 68.38 & $0.008 \pm 0.002^{a}$ & ND & ND & ND & ND & ND & ND \\
\hline 23 & Hexadecanoic acid, ethyl ester* & 71.83 & $0.28 \pm 0.15^{\mathrm{a}}$ & $0.082 \pm 0.02^{\mathrm{a}}$ & $2.19 \pm 0.36^{b}$ & $0.016 \pm 0.01^{\mathrm{a}}$ & $0.121 \pm 0.02^{\mathrm{a}}$ & $0.022 \pm 0.00^{\mathrm{a}}$ & $0.059 \pm 0.04^{\mathrm{a}}$ \\
\hline 24 & Decanedioic acid, diethyl ester & 78.89 & $0.043 \pm 0.02$ & ND & ND & ND & ND & ND & ND \\
\hline 25 & 8-Nonenoic acid, ethyl ester & 81.85 & $0.016 \pm 0.01$ & ND & ND & ND & ND & ND & ND \\
\hline 26 & (E)-9-Octadecenoic acid ethyl ester & 98.55 & $0.298 \pm 0.23^{\mathrm{a}}$ & ND & $3.93 \pm 0.69^{b}$ & ND & $0.098 \pm 0.02^{a}$ & ND & $0.022 \pm 0.01^{\mathrm{a}}$ \\
\hline \multicolumn{10}{|c|}{ (D) } \\
\hline 27 & Ethanol* & 7.06 & $4.169 \pm 1.56^{\mathrm{b}}$ & $3.095 \pm 1.72 \mathrm{ab}$ & $4.404 \pm 0.36^{\mathrm{b}}$ & $4.21 \pm 3.06^{\mathrm{b}}$ & $0.9 \pm 0.52^{\mathrm{a}}$ & $1.67 \pm 0.75^{\mathrm{a}}$ & $1.038 \pm 0.45^{\mathrm{a}}$ \\
\hline 28 & 1-Pentanol* & 20.34 & $0.101 \pm 0.04^{\mathrm{a}}$ & $0.135 \pm 0.06^{\mathrm{a}}$ & $0.15 \pm 0.01^{\mathrm{a}}$ & $0.199 \pm 0.18^{\mathrm{a}}$ & $0.036 \pm 0.01^{\mathrm{a}}$ & $0.033 \pm 0.02^{a}$ & $0.022 \pm 0.01^{\mathrm{a}}$ \\
\hline 29 & 2,6-Octadien-1-ol,3,7-dimethyl-,acetate, (Z) & 41.62 & ND & ND & ND & ND & $0.029 \pm 0.00^{\mathrm{a}}$ & $0.001 \pm 0.00^{\mathrm{a}}$ & $0.009 \pm 0.00^{b}$ \\
\hline 30 & Benzyl alcohol & 48.24 & ND & $0.006 \pm 0.00$ & ND & ND & ND & ND & ND \\
\hline 31 & Phenylethyl Alcohol * & 50.69 & $1.125 \pm 0.43^{\mathrm{cd}}$ & $2.096 \pm 0.78^{\mathrm{e}}$ & $1.597 \pm 0.18$ de & $0.901 \pm 0.7 \mathrm{bc}$ & $0.322 \pm 0.06^{\mathrm{ab}}$ & $0.225 \pm 0.12 \mathrm{ab}$ & $0.16 \pm 0.01^{\mathrm{a}}$ \\
\hline
\end{tabular}


Table 4. Cont.

\begin{tabular}{|c|c|c|c|c|c|c|c|c|c|}
\hline \multirow{2}{*}{ No. } & \multirow{2}{*}{ Volatile Compound } & \multirow{2}{*}{ RT } & \multicolumn{4}{|c|}{ Artisanal Tejuino } & \multicolumn{3}{|c|}{ Commercial Tejuino } \\
\hline & & & AR & AW & AY & TC & TL & TM & TT \\
\hline \multicolumn{10}{|c|}{ Organic acids } \\
\hline 32 & Alpha-pyrone-6-carboxylic acid & 28.95 & ND & ND & ND & $0.035 \pm 0.03^{\mathrm{a}}$ & ND & $0.003 \pm 0.00^{\mathrm{a}}$ & ND \\
\hline 33 & Acetic acid & 30.2 & ND & $0.022 \pm 0.02^{\mathrm{a}}$ & $0.557 \pm 0.04^{\mathrm{a}}$ & ND & ND & $0.003 \pm 0.00^{\mathrm{a}}$ & $0.067 \pm 0.04^{\mathrm{a}}$ \\
\hline 34 & Butanoic acid & 38.06 & ND & ND & ND & ND & ND & ND & $0.183 \pm 0.04^{\mathrm{a}}$ \\
\hline 35 & Octanoic acid & 58.85 & $0.161 \pm 0.07^{\mathrm{a}}$ & $0.118 \pm 0.12^{\mathrm{a}}$ & $0.32 \pm 0.04^{\mathrm{a}}$ & $1.264 \pm 0.92^{b}$ & $0.019 \pm 0.02^{\mathrm{a}}$ & $0.072 \pm 0.08^{a}$ & $0.02 \pm 0.00^{\mathrm{a}}$ \\
\hline 36 & Sorbic Acid & 63.57 & ND & ND & ND & ND & ND & ND & $0.023 \pm 0.00$ \\
\hline 37 & n-Decanoic acid & 72.6 & $0.065 \pm 0.02^{b}$ & $0.063 \pm 0.02^{\mathrm{ab}}$ & ND & $0.257 \pm 0.14^{\mathrm{a}}$ & ND & $0.054 \pm 0.02^{\mathrm{ab}}$ & $0.033 \pm 0.03^{\mathrm{ab}}$ \\
\hline 39 & 1 1 9-Decenoic acid & 79.15 & ND & ND & ND & $0.0222 \pm 0.01$ & ND & ND & ND \\
\hline 40 & Benzoic acid & 88.42 & ND & ND & ND & ND & $0.004 \pm 0.00^{\mathrm{a}}$ & ND & $0.154 \pm 0.00^{\mathrm{a}}$ \\
\hline \multicolumn{10}{|c|}{ Terpenes } \\
\hline 41 & $\beta$-Phellandrene & 12.64 & ND & ND & ND & ND & $0.002 \pm 0.00$ & ND & ND \\
\hline 42 & $\beta$-Pinene & 15.93 & ND & ND & ND & ND & $0.012 \pm 0.00^{\mathrm{a}}$ & ND & $0.0048 \pm 0.00^{\mathrm{a}}$ \\
\hline 43 & $\beta$-Myrcene & 16.02 & ND & ND & ND & ND & ND & $0.001 \pm 0.00$ & ND \\
\hline 44 & D-Limonene & 17.56 & $0.012 \pm 0.01^{\mathrm{a}}$ & $0.003 \pm 0.00^{\mathrm{a}}$ & ND & ND & $0.299 \pm 0.11^{\mathrm{a}}$ & $0.026 \pm 0.01^{\mathrm{a}}$ & $0.096 \pm 0.07^{\mathrm{a}}$ \\
\hline 45 & $\gamma$-Terpinene & 19.48 & ND & ND & ND & ND & $0.06 \pm 0.01$ & ND & ND \\
\hline 46 & o-Cymene & 21.67 & ND & ND & ND & ND & $0.075 \pm 0.01^{\mathrm{a}}$ & ND & $0.007 \pm 0.00^{\mathrm{a}}$ \\
\hline 48 & Terpinen-4-ol & 37.81 & ND & ND & ND & ND & $0.008 \pm 0.00^{\mathrm{a}}$ & $0.005 \pm 0.00^{\mathrm{a}}$ & ND \\
\hline 49 & L- $\alpha$-Terpineol & 40.79 & ND & ND & ND & ND & $0.026 \pm 0.00^{\mathrm{a}}$ & $0.003 \pm 0.00^{\mathrm{a}}$ & $0.004 \mathrm{a} \pm 0.00^{\mathrm{a}}$ \\
\hline 50 & $\beta$-Bisabolene & 41.29 & ND & ND & ND & ND & $0.145 \pm 0.01^{\mathrm{a}}$ & $0.023 \pm 0.01^{\mathrm{a}}$ & $0.042 \pm 0.01^{b}$ \\
\hline \multicolumn{10}{|c|}{ Aldehydes } \\
\hline 51 & Hexanal & 12.62 & ND & $0.011 \pm 0.00^{\mathrm{a}}$ & ND & ND & ND & ND & ND \\
\hline 52 & Nonanal & 29.6 & ND & $0.038 \pm 0.01^{\mathrm{a}}$ & ND & $0.014 \pm 0.02^{\mathrm{a}}$ & ND & ND & ND \\
\hline 53 & 3-Furaldehyde & 32 & $0.006 \pm 0.00^{b}$ & $0.013 \pm 0.01 \mathrm{ab}$ & ND & $0.068 \pm 0.063^{\mathrm{ab}}$ & ND & $0.002 \pm 0.00 \mathrm{ab}$ & $0.017 \pm 0.01^{\mathrm{a}}$ \\
\hline 54 & 2,4-Heptadienal, (E,E) & 33.52 & ND & $0.025 \pm 0.01$ & ND & ND & ND & ND & ND \\
\hline 55 & Benzaldehyde * & 34.11 & $0.046 \pm 0.02^{c}$ & $0.172 \pm 0.06^{\mathrm{ab}}$ & $0.041 \pm 0.00 \mathrm{bc}$ & $0.17 \pm 0.14 \mathrm{abc}$ & $0.034 \pm 0.00^{\mathrm{abc}}$ & $0.007 \pm 0.00^{\mathrm{d}}$ & $0.013 \pm 0.00^{\mathrm{a}}$ \\
\hline 56 & 2-Nonenal, (E) & 35.11 & ND & $0.078 \pm 0.03^{\mathrm{a}}$ & ND & ND & ND & ND & ND \\
\hline 57 & 2-Furancarboxaldehyde, 5-methyl- & 37.11 & $0.007 \pm 0.00^{b}$ & $0.023 \pm 0.01 \mathrm{ab}$ & $0.006 \pm 0.00^{\mathrm{ab}}$ & $0.049 \pm 0.04^{\mathrm{ab}}$ & $0.004 \pm 0.00^{b}$ & ND & $0.013 \pm 0.00^{\mathrm{a}}$ \\
\hline 58 & 2-Decenal, (E) & 39.33 & ND & $0.107 \pm 0.03$ & ND & ND & ND & ND & ND \\
\hline 59 & Benzaldehyde, 4-methyl & 39.58 & ND & $0.099 \pm 0.04^{\mathrm{a}}$ & $0.007 \pm 0.00^{\mathrm{a}}$ & $0.236 \pm 0.18^{a}$ & ND & $0.014 \pm 0.01^{\mathrm{a}}$ & $0.027 \pm 0.01^{\mathrm{a}}$ \\
\hline 60 & 2,4-Nonadienal, (E,E) & 41.23 & $0.005 \pm 0.00^{\mathrm{a}}$ & $0.111 \pm 0.03^{\mathrm{a}}$ & $0.003 \pm 0.00^{\mathrm{a}}$ & ND & ND & ND & ND \\
\hline 61 & 2-Undecenal & 42.77 & ND & $0.057 \pm 0.01$ & ND & ND & ND & ND & ND \\
\hline 62 & 3-Acetyl-1H-pyrroline & 55.11 & $0.002 \pm 0.00^{\mathrm{a}}$ & $0.008 \pm 0.00^{b}$ & $0.003 \pm 0.00^{\mathrm{a}}$ & $0.032 \pm 0.02^{\mathrm{a}}$ & ND & ND & ND \\
\hline
\end{tabular}


Table 4. Cont.

\begin{tabular}{|c|c|c|c|c|c|c|c|c|c|}
\hline \multirow{2}{*}{ No. } & \multirow{2}{*}{ Volatile Compound } & \multirow{2}{*}{ RT } & \multicolumn{4}{|c|}{ Artisanal Tejuino } & \multicolumn{3}{|c|}{ Commercial Tejuino } \\
\hline & & & AR & AW & AY & TC & TL & TM & TT \\
\hline \multicolumn{10}{|c|}{ Benzenes } \\
\hline 63 & Toluene & 9.97 & ND & $0.002 \pm 0.00^{\mathrm{a}}$ & ND & $0.008 \pm 0.01^{\mathrm{a}}$ & $0.002 \pm 0.00^{\mathrm{a}}$ & ND & $0.001 \pm 0.00^{\mathrm{a}}$ \\
\hline 64 & Pyridine & 19.4 & ND & ND & ND & ND & ND & ND & ND \\
\hline 65 & Ether, 3-methyl-2-butenyl o-tolyl & 16.07 & ND & ND & ND & $0.0383 \pm 0.03$ & ND & ND & ND \\
\hline 66 & Benzene, $1,1^{\prime}-(1,2-$ cyclobutanediyl)bis-, cis & 21.69 & $0.014 \pm 0.00^{\mathrm{a}}$ & $0.014 \pm 0.01^{\mathrm{a}}$ & ND & ND & ND & ND & ND \\
\hline 67 & Benzofuran, 2-methyl- & 37.19 & ND & ND & ND & ND & ND & $0.007 \pm 0.00$ & ND \\
\hline 68 & Naphthalene & 42.33 & $0.003 \pm 0.00^{\mathrm{a}}$ & ND & $0.013 \pm 0.00^{\mathrm{a}}$ & $0.006 \pm 0.01^{\mathrm{a}}$ & ND & $0.021 \pm 0.01^{\mathrm{a}}$ & ND \\
\hline 70 & Phenol, 2-methoxy & 47.29 & ND & $0.019 \pm 0.01^{\mathrm{a}}$ & ND & $0.024 \pm 0.01^{\mathrm{a}}$ & ND & ND & ND \\
\hline 71 & Mequinol & 47.57 & ND & ND & ND & ND & ND & ND & $0.002 \pm 0.00$ \\
\hline 72 & Benzene, 1,4-diethoxy- & 51.56 & ND & $0.054 \pm 0.02$ & ND & ND & ND & ND & ND \\
\hline 73 & Creosol & 53.49 & $0.069 \pm 0.03^{b c d}$ & $0.796 \pm 0.03^{\mathrm{d}}$ & $0.022 \pm 0.00^{\mathrm{a}}$ & $0.033 \pm 0.02^{\mathrm{ab}}$ & $0.043 \pm 0.01^{\mathrm{abc}}$ & $0.002 \pm 0.00^{\mathrm{abc}}$ & $0.004 \pm 0.00^{\mathrm{abcd}}$ \\
\hline 74 & Phenol, 3-methyl & 56.22 & ND & ND & ND & ND & ND & $0.005 \pm 0.00$ & ND \\
\hline 75 & Phenol, 4-ethyl-2-methoxy- * & 57.54 & $0.222 \pm 0.09^{a}$ & $0.59 \pm 0.21^{b}$ & $0.283 \pm 0.02 \mathrm{ab}$ & $0.22 \pm 0.13 \mathrm{ab}$ & $0.033 \pm 0.00^{\mathrm{ab}}$ & $0.031 \pm 0.01 \mathrm{ab}$ & $0.215 \pm 0.01^{\mathrm{a}}$ \\
\hline 76 & p-Cresol & 59.66 & $0.006 \pm 0.00^{b}$ & $0.032 \pm 0.02 \mathrm{ab}$ & $0.028 \pm 0.00 \mathrm{ab}$ & $0.005 \pm 0.00 \mathrm{ab}$ & $0.001 \pm 0.00^{\mathrm{a}}$ & $0.003 \pm 0.00^{\mathrm{ab}}$ & $0.003 \pm 0.00 \mathrm{ab}$ \\
\hline 77 & Phenol, 3-ethyl & 59.79 & ND & $0.013 \pm 0.00^{\mathrm{ab}}$ & $0.012 \pm 0.00^{\mathrm{a}}$ & ND & ND & $0.004 \pm 0.00^{\mathrm{ab}}$ & ND \\
\hline \multicolumn{10}{|c|}{ - } \\
\hline 80 & 2-Vinylfuran & 11.7 & ND & ND & ND & $0.005 \pm 0.00$ & ND & ND & ND \\
\hline 81 & Methyl vinyl ketone & 14.95 & ND & ND & $0.008 \pm 0.00$ & ND & ND & ND & ND \\
\hline 82 & Propene & 15.6 & ND & ND & ND & ND & ND & $0.001 \pm 0.00^{\mathrm{a}}$ & ND \\
\hline 83 & Methanesulfonic anhydride & 19.52 & $0.001 \pm 0.00^{\mathrm{a}}$ & $0.013 \pm 0.00^{\mathrm{a}}$ & ND & $0.002 \pm 0.00^{\mathrm{a}}$ & ND & ND & ND \\
\hline 84 & Furan, 2-pentyl & 20.62 & ND & ND & ND & $0.035 \pm 0.04^{\mathrm{a}}$ & ND & ND & ND \\
\hline 85 & Cyclopentane, methyl & 27.6 & $0.005 \pm 0.00^{\mathrm{a}}$ & ND & ND & $0.063 \pm 0.06^{\mathrm{a}}$ & ND & ND & ND \\
\hline 86 & Ethanone, 1-(2-furanyl) & 33.89 & ND & ND & ND & $0.06 \pm 0.07^{\mathrm{a}}$ & ND & $0.005 \pm 0.01^{\mathrm{a}}$ & ND \\
\hline 87 & Cyclopropane, pentyl & 35.27 & $0.007 \pm 0.00^{\mathrm{a}}$ & $0.019 \pm 0.01^{\mathrm{a}}$ & ND & $0.138 \pm 0.13^{\mathrm{a}}$ & ND & ND & ND \\
\hline 88 & Hexadecane & 37.52 & ND & $0.007 \pm 0.00$ & ND & ND & ND & ND & ND \\
\hline 89 & $\begin{array}{l}\text { Bicyclo[6.1.0]nonane, } \\
\text { 9-(1-methylethylidene) }\end{array}$ & 40.31 & ND & $0.019 \pm 0.01$ & ND & ND & ND & ND & ND \\
\hline
\end{tabular}

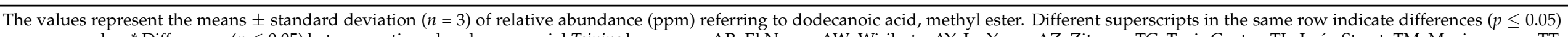

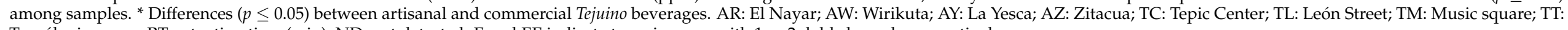
Tecnólogico zone; RT: retention time (min); ND: not detected. E and EE indicate trans isomers with 1 or 2 doble bounds, respectively. 
Although alcohols were not the predominant group, it is important to highlight that ethanol showed the highest concentration, mainly for artisanal beverages, with 4.17, 3.01, 4.40, and 4.21 ppm, followed by phenyl ethyl alcohol with 1.13, 2.01, 1.6, and 0.9 ppm for "AR", "AW", "AY" and "AZ", respectively. In this sense, the higher alcohol concentration in the artisanal sample could be attributed to the presence of Saccharomyces cerevisiae. This yeast produces enzymes such as amylases, lipases, esterases, and phytases which promote flavor and aroma, and are the most employed for ethanol production, ketones, aldehydes, and esters. Furthermore, the high LAB concentration may favor the enzymes production for hydrolyzing corn starch and the yeasts used for their metabolism, which release vitamins and soluble nitrogen for LAB growth [45]. Other cereal-based fermented co-cultures of LAB and yeast showed a higher alcohol content [46].

Other compounds such as methanesulfonic anhydride, furan 2-penty, ethenone 1-(2furanyl), and cyclopropane pentyl were in both types of Tejuino; meanwhile, 2-vinylfuran, methyl vinyl ketone, cyclopentane methyl, hexadecane, and bicycle(6.1.0)nonane, 9-(1mehtylethylidene) were found only in artisanal samples. For germinated maize, the volatile compounds such as lactic acid, 2,3-butanediol, dodecane, benzofurans, and tridecane are produced by microorganisms such as Lactobacillus plantarum and Lactococcus lactis [21].

Additionally, the analysis of the PCA showed the clustering of volatile compounds and Tejuino sample (Figure 1). Figure 1a shows the PCA of 89 identified compounds, and three main groups were identified by the k-means cluster analysis and explained with $81.39 \%, 6.13 \%$, and 5.05\% for PC1, PC2, and PC3, respectively. In cluster A found showed the highest concentration of volatile compounds and ethanol was included. In cluster $\mathrm{B}$ are compounds that did not show a significant difference; cluster $C$ only contained tree compounds (decanoic acid ethyl ester, hexadecenoic acid ethyl ester, and (E)-9-octadecenoic acid ethyl ester).
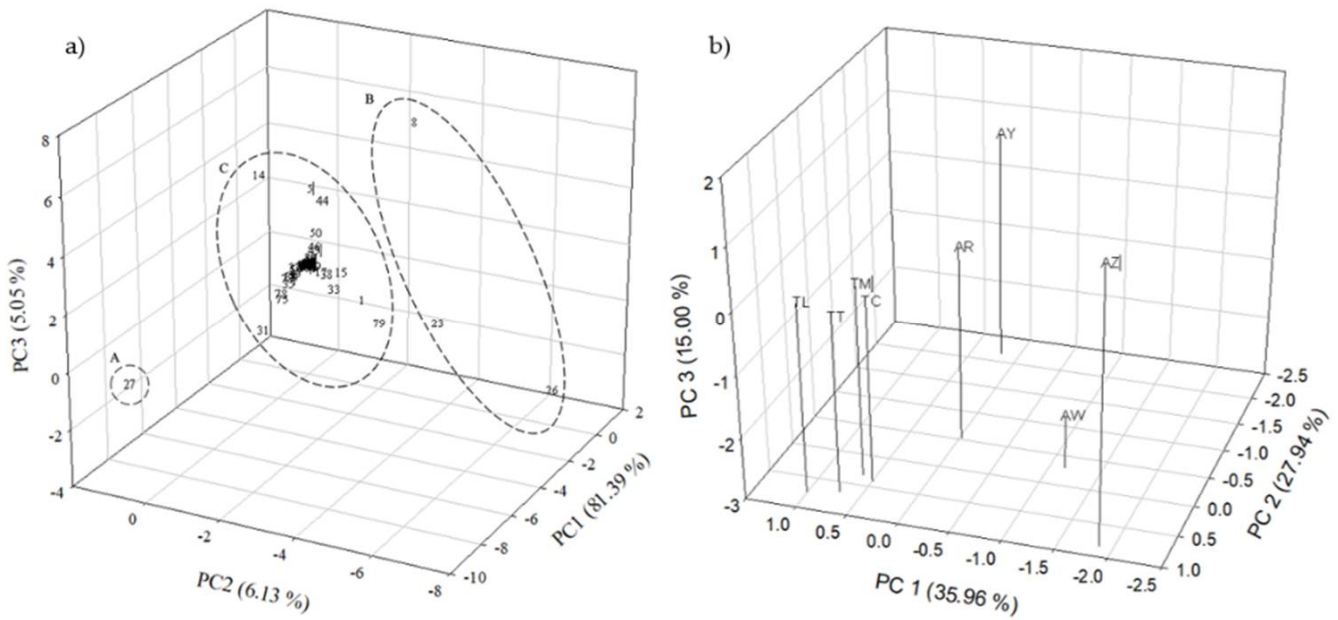

Figure 1. Principal component analysis (PCA). (a) PCA of the first three factor scores and factor loadings of volatile compounds of all samples of Tejuino fresh artisanal and commercial samples. (b) PCA of the three first factor loadings of samples of Tejuino. AR: El Nayar; AW: Wirikuta; AY: La Yesca; AZ: Zitacua; TC: Tepic Center; TL: León Street; TM: Music square; TT: Tecnólogico zone.

The PCA for Tejuino samples is shown in Figure 1b. This analysis showed three components that explained the $35.96 \%, 27.94 \%$, and $15.00 \%$ for PC1, PC2, and PC3, respectively. Commercial beverages (TC, TL, TM, and TT) were grouped at the same cluster. However, artisanal beverages (AR, AW, AY, and AZ) showed a high dispersion, indicating a higher variability among them, considering the distribution of the identified volatile compounds.

Volatile compounds such as esters derived from fatty acids detected in this study could promote fruity notes and have been related to the presence of yeast strains such as Saccharomyces cerevisiae [47-49]. Thus, the esters found in Tejuino samples could be attributed to their content of alcohols, which are precursors of these compounds [50]. 
On the other hand, the content of ethanol was associated with Saccharomyces cerevisiae, which is the most commonly employed yeast for ethanol production [51,52], and this was identified for the artisanal samples of our study. Moreover, yeast produces longchain and complex alcohols that, together with esters, have an interesting flavor, such as phenylethanol, which possesses a rose-like aroma [53,54], as well as sweet alcohol, rough, and fruity aromas [55].

On the other hand, D-limonene (terpene) was reported in both samples and has been associated with a lemon-like [56], flowery, and lilac odor $[57,58]$. The compounds and $\beta$-myrcene were reported in others beverages composed of maize [58]. Otherwise, aldehydes were found in both types of Tejuino. For instance, hexanal has been identified in other cereal-based fermented products and sorghum malt beverages, and has been reported having strong antimicrobial properties against pathogenic microorganisms at low concentrations [59,60].

The relative abundance for aldehydes, only for artisanal Tejuino, may be attributed to soaking that disrupt the physical structure to release volatile compounds and enhance lipoxygenase activity [61]. The fermentative changes directly influence final fermented physical properties, chemical, biological, and sensory properties. This activity is associated with microorganisms, which generate various volatile compounds that promote the development of flavors in fermented foods [62].

\section{Conclusions}

Their production process primarily determined the physicochemical characteristics and microbiological quality of the Tejuino beverages. In this aspect, the artisanal beverage was outstanding, and showed a great diversity of volatile compounds. The isolated microorganisms identified were yeasts and lactic acid bacteria, which may be considered for future studies to evaluate the potential bioactivity for their use in industrial processes, as well as an examination of microbiota, which could be carried out to assess its possible potential use in the production of compounds with a biotechnological application.

This study allowed us to know and update the available information on this important traditional fermented beverage of Mexico.

Author Contributions: Conceptualization, A.F.G.-C. and S.G.S.-A.; Methodology, Á.E.R.-C., A.F.G.-C. and S.G.S.-A.; Software and Formal analysis, Á.E.R.-C., R.R.-D. and J.I.M.-R.; Investigation, Á.E.R.-C., A.H.-M., B.V.-C., A.F.G.-C. and S.G.S.-A.; Writing-original draft preparation, Á.E.R.-C.; Writingreview and editing, L.S.-L., A.H.-M. and B.V.-C.; Supervision and Project administration, A.F.G.-C. and S.G.S.-A. All authors have read and agreed to the published version of the manuscript.

Funding: Á.E.R.-C. and S.G.S.-A. acknowledge TecNM for the financial support 10368.21-P and CONACYT for the project FOP02-2021-04-316948 and the PRODEP program and the net ALSUBCYTED 118RT0543.

Institutional Review Board Statement: Not applicable.

Informed Consent Statement: Not applicable.

Data Availability Statement: The data presented in this study are available on request from the corresponding author.

Acknowledgments: Á.E.R.-C. acknowledges the Mexican Council of Science and Technology (CONACyT) for the graduate scholarship (registration number: 296712).

Conflicts of Interest: The authors declare that they have no conflict of interest.

\section{References}

1. Siyuan, S.; Tong, L.; Liu, R. Corn phytochemicals and their health benefits. Food Sci. Human Well. 2018, 73, 185-195. [CrossRef]

2. Nkhata, S.G.; Ayua, E.; Kamau, E.H.; Shingiro, J.B. Fermentation and germination improve nutritional value of cereals and legumes through activation of endogenous enzymes. Food Sci. Nutr. 2018, 6, 2446-2458. [CrossRef] [PubMed]

3. Mashau, M.E.; Maliwichi, L.L.; Jideani, A.I.O. Non-alcoholic fermentation of maize (Zea mays) in Sub-Saharan Africa. Fermentation 2021, 7, 158. [CrossRef] 
4. Ramírez-Guzmán, K.N.; Torres-León, C.; Martinez-Medina, G.A.; de la Rosa, O.; Hernández-Almanza, A.; Alvarez-Perez, O.B.; Araaujo, R.; González, R.L.; Londoño, L.; Ventura, J.; et al. Traditional fermented beverages in Mexico. In Fermented Beverages; Woodhead Publishing: Sawston, UK, 2019; pp. 605-635.

5. Rubio-Castillo, Á.E.; Santiago-López, L.; Vallejo-Cordoba, B.; Hernández-Mendoza, A.; Sayago-Ayerdi, S.G.; González-Córdova, A.F. Traditional non-distilled fermented beverages from Mexico to based on maize: An approach to Tejuino beverage. Int. J. Gastron. Foods Sci. 2021, 23, 100283. [CrossRef]

6. Wacher-Rodarte, C. Alimentos y bebidas fermentados tradicionales. Biotecnologıa Alimentaria; Grupo Noriega, Editorial LIMUSA: Mexico City, Mexico, 1995; pp. 313-349.

7. Sangwan, S.; Kumar, S.; Goyal, S. Maize utilisation in food bioprocessing: An overview. In Maize: Nutrition Dynamics and Novel Uses; Chaudhary, D.P., Kumar, S.S., Eds.; Springer: New Delhi, India, 2014; pp. 119-134.

8. Chaves-López, C.; Serio, A.; Grande-Tovar, C.D.; Cuervo-Mulet, R.; Delgado-Ospina, J.; Paparella, A. Traditional fermented foods and beverages from a microbiological and nutritional perspective: The Colombian heritage. Compr. Rev. Food Sci. Food Saf. 2014, 13, 1031-1048. [CrossRef]

9. Robledo-Márquez, K.; Ramírez, V.; González-Córdova, A.F.; Ramírez-Rodríguez, Y.; García-Ortega, L.; Trujillo, J. Research opportunities: Traditional fermented beverages in Mexico. Cultural, microbiological, chemical, and functional aspects. Food Res. Int. 2021, 147, 110482. [CrossRef]

10. Coelho, E.; Lemos, M.; Genisheva, Z.; Domingues, L.; Vilanova, M.; Oliveira, J.M. Validation of a LLME/GC-MS methodology for quantification of volatile compounds in fermented beverages. Molecules 2020, 25, 621. [CrossRef] [PubMed]

11. Hirst, M.B.; Richter, C.L. Review of aroma formation through metabolic pathways of Saccharomyces cerevisiae in beverage fermentations. Am. J. Enol. Vitic. 2016, 67, 361-370. [CrossRef]

12. AOAC. International Official Methods of Analysis, 17th ed.; AOAC Int.: Gaithersburg, MD, USA, 2000.

13. Wisker, E.; Feldheim, W. Metabolizable energy of diets low or high in dietary fiber from fruits and vegetables when consumed by humans. J. Nutr. 1990, 120, 1331-1337. [CrossRef]

14. Torres-Llanez, M.J.; Vallejo-Cordoba, B.; Díaz-Cinco, M.E.; Mazorra-Manzano, M.A.; González-Córdova, A.F. Characterization of the natural microflora of artisanal Mexican Fresco cheese. Food Control. 2006, 17, 683-690. [CrossRef]

15. Secretaria de Salud. NOM-111-1994. Bienes y Servicios. Método para la Cuenta de Mohos y Levaduras en Alimentos. Diario Oficial de la Federación. Available online: http:/ /www.economia-noms.gob.mx/normas/noms/1995/111-ssa1.pdf (accessed on 1 August 2021).

16. Secretaria de Salud. NOM-092-1994. Bienes y Servicios. Método para la Cuenta de Bacterias Aerobias en Placa. Diario Oficial de la Federación. Available online: http:/ / www.dof.gob.mx/nota_detalle.php?codigo=4728921\&fecha=15/08/1994\&print=true (accessed on 1 August 2021).

17. Secretaria de Salud. NOM-112-1994. Bienes y Servicios. Determinación de Bacterias Coliformes. Técnica del Número más Probable. Diario Oficial de la Federación. Available online: http: / / dof.gob.mx/nota_detalle.php?codigo=4728925\&fecha=15/08 / 1994 (accessed on 1 August 2021).

18. Chen, Y.S.; Yanagida, F.; Shinohara, T. Isolation and identification of lactic acid bacteria from soil using an enrichment procedure. Lett. Appl. Microbiol. 2005, 40, 195-200. [CrossRef] [PubMed]

19. Marino, M.; Maifreni, M.; Rondinini, G. Microbiological characterization of artisanal Montasio cheese: Analysis of its indigenous lactic acid bacteria. FEMS Microbiol. Lett. 2003, 229, 133-140. [CrossRef]

20. Reyes-Díaz, R.; González-Córdova, A.F.; Estrada-Montoya, M.D.C.; Méndez-Romero, J.I.; Mazorra-Manzano, M.A.; Soto-Valdez, H.; Vallejo-Cordoba, B. Volatile and sensory evaluation of Mexican Fresco cheese as affected by specific wild Lactococcus lactis strains. J. Dairy Sci. 2020, 103, 242-253. [CrossRef] [PubMed]

21. Hiran, P.; Kerdchoechuen, O.; Laohakunjit, N. Combined effects of fermentation and germination on nutritional compositions, functional properties and volatiles of maize seeds. J. Cereal Sci. 2016, 71, 207-216. [CrossRef]

22. Frias, J.; Miranda, M.L.; Doblado, R.; Vidal-Valverde, C. Effect of germination and fermentation on the antioxidant vitamin content and antioxidant capacity of Lupinus albus L. var. Multolupa. Food Chem. 2005, 92, 211-220. [CrossRef]

23. Lara-Núñez, A.; García-Ayala, B.B.; Garza-Aguilar, S.M.; Flores-Sánchez, J.; Sánchez-Camargo, V.A.; Bravo-Alberto, C.E.; VázquezSantana, S.; Vázquez-Ramos, J.M. Glucose and sucrose differentially modify cell proliferation in maize during germination. Plant Physiol. Biochem. 2017, 113, 20-31. [CrossRef]

24. Gernah, D.I.; Ariahu, C.C.; Ingbian, E.K. Effects of malting and lactic fermentation on some chemical and functional properties of maize (Zea mays). Am. J. Food Technol. 2011, 6, 404-412. [CrossRef]

25. Ben Omar, N.; Ampe, F. Microbial community dynamics during production of the Mexican fermented maize dough pozol. Appl. Environ. Microbiol. 2000, 66, 3664-3673. [CrossRef]

26. Cocolin, L.; Manzano, M.; Cantoni, C.; Comi, G. Denaturing gradient gel electrophoresis analysis of the 16S rRNA gene V1 region to monitor dynamic changes in the bacterial population during fermentation of Italian sausages. Appl. Environ. Microbiol. 2001, 67, 5113-5121. [CrossRef]

27. Díaz-Ruiz, G.; Guyot, J.P.; Ruiz-Teran, F.; Morlon-Guyot, J.; Wacher, C. Microbial and physiological characterization of weakly amylolytic but fast-growing lactic acid bacteria: A functional role in supporting microbial diversity in pozol, a Mexican fermented maize beverage. Appl. Environ. Microbiol. 2003, 69, 4367-4374. [CrossRef] 
28. Pérez-Cataluña, A.; Elizaquível, P.; Carrasco, P.; Espinosa, J.; Reyes, D.; Wacher, C.; Aznar, R. Diversity and dynamics of lactic acid bacteria in Atole agrio, a traditional maize-based fermented beverage from South-Eastern Mexico, analysed by high throughput sequencing and culturing. Antonie Leeuwenhoek 2018, 111, 385-399. [CrossRef] [PubMed]

29. Jiménez Espinoza, A.S. Identificación de la Capacidad Biotransformadora, de Bacterias Acido Lácticas Nativas de Tres Productos Artesanales (Queso Adobera, Tejuino y Pulque) para Convertir Acido Linoleico en Acido Linoleico Conjugado [Centro de Investigación y Asistencia en Tecnología del Estado de Jalisco]. 2017. Available online: https://ciatej.repositorioinstitucional.mx/ jspui/bitstream/1023/426/1/SandraJimenezEspinoza.pdf (accessed on 8 August 2021).

30. Kousta, M.; Mataragas, M.; Skandamis, P.; Drosinos, E.H. Prevalence and sources of cheese contamination with pathogens at farm and processing levels. Food Control 2010, 21, 805-815. [CrossRef]

31. Chaves-López, C.; Rossi, C.; Maggio, F.; Paparella, A.; Serio, A. Changes occurring in spontaneous maize fermentation: An overview. Fermentation 2020, 6, 36. [CrossRef]

32. Grijalva-Vallejos, N.; Aranda, A.; Matallana, E. Evaluation of yeasts from Ecuadorian chicha by their performance as starters for alcoholic fermentations in the food industry. Int. J. Food Microbiol. 2020, 317, 108462. [CrossRef]

33. Ercolini, D. PCR-DGGE fingerprinting: Novel strategies for detection of microbes in food. J. Microbiol. Methods 2004, 56, 297-314. [CrossRef] [PubMed]

34. Kurtzman, C.; Fell, J.; Boekhout, T. The Yeasts, a Taxonomic Study, 5th ed.; Kurtzman, C., Fell, J.W., Boekhout, T., Eds.; Elsevier Science Ltd: Amsterdam, The Netherlands, 2011.

35. Chan, G.F.; Gan, H.M.; Ling, H.L.; Rashid, N.A.A. Genome sequence of Pichia kudriavzevii M12, a potential producer of bioethanol and phytase. Eukaryot. Cell. 2012, 11, 1300-1301. [CrossRef]

36. Ramadan, L.; Abdelaliem, Y.F.; Mahfoz, S.A. Biodiesel production by Pichia occidentalis MH879824. Int. J. Curr. Microbiol. 2019, 8, 2975-2987. [CrossRef]

37. Varela, C. The impact of non-Saccharomyces yeasts in the production of alcoholic beverages. Appl. Microbiol. Biotechnol. 2016, 100, 9861-9874. [CrossRef]

38. Ciani, M.; Mannazzu, I.; Domizio, P. Microbiota of fermented beverages. Fermentation 2018, 4, 78. [CrossRef]

39. Dirzo, G.S.; Ferrer, C.E.L.; Valadez, M.F.; Garfias, A.L.J.; Rodríguez, J.A.A.; Cruz, E.J.M.; Chilpa, R.R. Estudio preliminar del Axokot, bebida tradicional fermentada, bajo una perspectiva transdisciplinaria. Investig. Univ. Multidiscip. Rev. Investig. La Univ. Simón Bolívar 2010, 9, 12.

40. de la Fuente-Salcido, N.M.; Castañeda-Ramírez, J.C.; García-Almendárez, B.E.; Bideshi, D.K.; Salcedo-Hernández, R.; BarbozaCorona, J.E. Isolation and characterization of bacteriocinogenic lactic bacteria from M-Tuba and Tepache, two traditional fermented beverages in México. Food Sci. Nutr. 2015, 3, 434-442. [CrossRef]

41. Ramos, C.L.; Schwan, R.F. Technological and nutritional aspects of indigenous Latin America fermented foods. Curr. Opin. Food Sci. 2017, 13, 97-102. [CrossRef]

42. Ogodo, A.C.; Ugbogu, O.C.; Onyeagba, R.A.; Okereke, H.C. Effect of lactic acid bacteria consortium fermentation on the proximate composition and in-Vitro starch/protein digestibility of maize. Am. J. Microbiol. Biotechnol. 2017, 4, 35-43.

43. Chaves, R.D.; Pradella, F.; Turatti, M.A.; Amaro, E.C.; da Silva, A.R.; dos Santos Farias, A.; Pereira, J.L.; Khaneghah, A.M. Evaluation of Staphylococcus spp. in food and kitchen premises of Campinas, Brazil. Food Control 2018, 84, 463-470. [CrossRef]

44. Cheng, F. Volatile flavor compounds in yogurt: A Review. Crit. Rev. Food Sci. Nutr. 2010, 50, 938-950. [CrossRef] [PubMed]

45. Omemu, A.M.; Oyewole, O.B.; Bankole, M.O. Significance of yeasts in the fermentation of maize for ogi production. Food Microbiol. 2007, 24, 571-576. [CrossRef] [PubMed]

46. Menezes, A.G.T.; Ramos, C.L.; Dias, D.R.; Schwan, R.F. Combination of probiotic yeast and lactic acid bacteria as starter culture to produce maize-based beverages. Food Res. Int. 2018, 111, 187-197. [CrossRef]

47. Rojas, V.; Gil, J.V.; Piñaga, F.; Manzanares, P. Studies on acetate ester production by non-Saccharomyces wine yeasts. Int. J. Food Microbiol. 2001, 70, 283-289. [CrossRef]

48. Liu, S.-Q.; Holland, R.; Crow, V.L. Esters and their biosynthesis in fermented dairy products: A review. Int. Dairy J. 2004, 14, 923-945. [CrossRef]

49. Dutraive, O.; Benito, S.; Fritsch, S.; Beisert, B.; Patz, C.-D.; Rauhut, D. Effect of sequential inoculation with non-Saccharomyces and Saccharomyces yeasts on Riesling wine chemical composition. Fermentation 2019, 5, 79. [CrossRef]

50. Pires, E.J.; Teixeira, J.A.; Brányik, T.; Vicente, A.A. Yeast: The soul of beer's aroma-A review of flavour-active esters and higher alcohols produced by the brewing yeast. Appl. Microbiol. Biotechnol. 2014, 98, 1937-1949. [CrossRef] [PubMed]

51. Park, M.K.; Kim, Y.S. Distinctive formation of volatile compounds in fermented rice inoculated by different molds, yeasts, and lactic acid bacteria. Molecules 2019, 24, 2123. [CrossRef]

52. Vilela, J.D.A.S.; de Figueiredo Vilela, L.; Ramos, C.L.; Schwan, R.F. Physiological and genetic characterization of indigenous Saccharomyces cerevisiae for potential use in productions of fermented maize-based-beverages. Braz. J. Microbiol. 2020, 51, 1297-1307. [CrossRef]

53. Longo, M.A.; Sanromán, M.A. Production of food aroma compounds: Microbial and enzymatic methodologies. Food Technol. Biotechnol. 2006, 44, 335-353.

54. Cordente, A.G.; Espinase Nandorfy, D.; Solomon, M.; Schulkin, A.; Kolouchova, R.; Francis, I.L.; Schmidt, S.A. Aromatic higher alcohols in wine: Implication on aroma and palate attributes during Chardonnay aging. Molecules 2021, 26, 4979. [CrossRef] [PubMed] 
55. Dong, L.; Piao, Y.; Zhang, X.; Zhao, C.; Hou, Y.; Shi, Z. Analysis of volatile compounds from a malting process using headspace solid-phase micro-extraction and GC-MS. Food Res. Int. 2013, 51, 783-789. [CrossRef]

56. Freire, A.L.; Ramos, C.L.; Schwan, R.F. Effect of symbiotic interaction between a fructooligosaccharide and probiotic on the kinetic fermentation and chemical profile of maize blended rice beverages. Food Res. Int. 2017, 100, 698-707. [CrossRef]

57. Riu-Aumatell, M.; Miró, P.; Serra-Cayuela, A.; Buxaderas, S.; López-Tamames, E. Assessment of the aroma profiles of low-alcohol beers using HS-SPME-GC-MS. Food Res. Int. 2014, 57, 196-202. [CrossRef]

58. Romero-Medina, A.; Estarrón-Espinosa, M.; Verde-Calvo, J.R.; Lelièvre-Desmas, M.; Escalona-Buendía, H.B. Renewing traditions: A sensory and chemical characterisation of mexican pigmented corn beers. Foods 2020, 9, 886. [CrossRef]

59. Annan, N.T.; Poll, L.; Sefa-Dedeh, S.; Plahar, W.A.; Jakobsen, M. Volatile compounds produced by Lactobacillus fermentum, Saccharomyces cerevisiae and Candida krusei in single starter culture fermentations of Ghanaian maize dough. J. Appl. Microbiol. 2003, 94, 462-474. [CrossRef]

60. Fadida, T.; Selilat-Weiss, A.; Poverenov, E. N-hexylimine-chitosan, a biodegradable and covalently stabilized source of volatile, antimicrobial hexanal. Next generation controlled-release system. Food Hydrocoll. 2015, 48, 213-219. [CrossRef]

61. Sun, H.; Wang, H.; Zhang, P.; Ajlouni, S.; Fang, Z. Changes in phenolic content, antioxidant activity, and volatile compounds during processing of fermented sorghum grain tea. Cereal Chem. 2020, 97, 612-625. [CrossRef]

62. Dan, T.; Wang, D.; Jin, R.L.; Zhang, H.P.; Zhou, T.T.; Sun, T.S. Characterization of volatile compounds in fermented milk using solid-phase microextraction methods coupled with gas chromatography-mass spectrometry. J. Dairy Sci. 2017, 100, 2488-2500. [CrossRef] [PubMed] 